\title{
PENGELOLAAN EMBUNG DESA MENUJU DESA WISATA MELALUI BUMK TANJUNG ANOM
}

\author{
Aditya Wirawan*1, Taufik Raharjo ${ }^{2}$ \\ ${ }^{1,2}$ Politeknik Keuangan Negara STAN \\ Jl. Bintaro Utama Raya Sektor 5, Bintaro Jaya, Tangerang Selatan, Banten \\ *E-mail: adityawirawan08111984@gmail.com
}

\begin{abstract}
Kampung Tanjung Anom is a village located in Terusan Niliki Sub-district, Central Lampung Regency, Lampung Province. This village has made Retention Basin as a tourist attraction managed by Tanjung Anom Village-Owned Enterprise (BUMK), in the hope of being able to bring Village Revenue and be able to prosper society. This business went well, but gradually this business began to fade. Therefore, this community service activity aims to find the root of the problem that become the obstacle to the business development of BUMK and find solutions to the problem. This activity is carried out in two stages, namely Focus Group Discussion and mentoring. The results of the study can be concluded that the problems and the solutions to the deterioration of Tanjung Anom BUMK are: 1) Human Resources is a fundamental problem which is an obstacle to the development of Tanjung Anom BUMK. This problem began to erode after the full commitment of the BUMK managers. 2) The second problem is marketing, that the Tanjung Anom retention basin tourism object has not been well known in the eyes of the surrounding community. These are followed up by reviving social media and establishing communication with the communities in Lampung Province, 3) the last one is the problem of financial administration, we have not resolved this completely yet because it requires relatively much time.
\end{abstract}

Keywords - Village-Owned Enterprise, Tourism Village, Retention Basin, Lampung Province

\begin{abstract}
Abstrak
Kampung Tanjung Anom merupakan sebuah desa yang berada di Kecamatan Terusan Nunyai, Kabupaten Lampung Tengah, Provinsi Lampung. Kampung ini telah menjadikan embung desa sebagai lokasi wisata yang dikelola oleh Badan Usaha Milik Kampung (BUMK) Tanjung Anom, dengan harapan mampu mendatangkan Pendapatan Asli Desa dan mampu mensejahterakan masyarakat. Usaha ini berjalan lancar, namun lambat laun usaha ini mulai meredup. Sehingga kegiatan pengabdian kepada masyarakat ini bertujuan untuk mencari akar masalah yang menjadi kendala perkembangan usaha BUMK dan mencari solusi atas masalah tersebut. Kegiatan ini dilaksanakan dengan dua tahapan, yaitu Focus Group Discussion dan pendampingan. Hasil penelitian dapat disimpulkan bahwa permasalahan dan solusi keterpurukan BUMK Tanjung Anom adalah: 1) Sumber Daya Manusia merupakan masalah mendasar yang menjadi kendala perkembangan BUMK Tanjung Anom ini. Permasalahan ini mulai terkikis setelah adanya komitmen penuh dari para pengelola BUMK. 2) Masalah kedua adalah pemasaran, objek wisarata embung Tanjung Anom ini belum terkenal di mata masyarakat sekitar. Hal ini di tindaklanjuti dengan menghidupkan kembali media sosial dan memjalin komunikasi dengan komunitas-komunitas yang ada di Lampung, 3) Terakhir masalaah administrasi keuangan, hal ini belum kami selesaikan secara tuntas karena membutuhkan waktu yang relatif banyak.
\end{abstract}

Kata kunci-BUMDesa, Desa Wisata, Embung, Lampung

\section{PENDAHULUAN}

\subsection{Latar Belakang}

Kampung Tanjung Anom merupakan sebuah desa hasil program Transmigrasi Angkatan Darat (Trans AD) pada tahun Tahun 1974 yang berasal dari tiga Kesatuan Kodam TNI kala itu yakni dari Kodam Brawijaya (Jawa Timur), Kodam Diponegoro (Jawa Tengah) dan Kodam 
Siliwangi (Jawa Barat). Sehingga dapat dikatakan kampung ini dihuni oleh anak-anak tentara. Kampung Tanjung Anom berada di Kecamatan Terusan Nunyai, Kabupaten Lampung Tengah, Provinsi Lampung. Lokasi kampung Tanjng Anom tak jauh dari jalan lintas timur Sumatera yang menghubungkan antara Provinsi Lampung dan Provinsu Sumatera Selatan. Pada saat ini, Kelapa Pemerintahan dipegang oleh Bapak Wasis Trisno Hadi selaku Kepala Kampung terpilih. Kampung Tanjung Anom memiliki luas area sekitar 1.249 hektar, dengan potensi alam yang terdiri dari lahan-lahan perkebunan baik untuk tebu dan singkong. Potensi Sumber Daya Manusia dengan penduduk sedkitar 6.000 penduduk atau 1459 KK. Pekerjaan 80\% sebagai karyawan di perusahaan sekitar kampung, $17 \%$ sebagai petani perkebunan baik tebu maupun singkong, dan PNS sekitar $3 \%$.

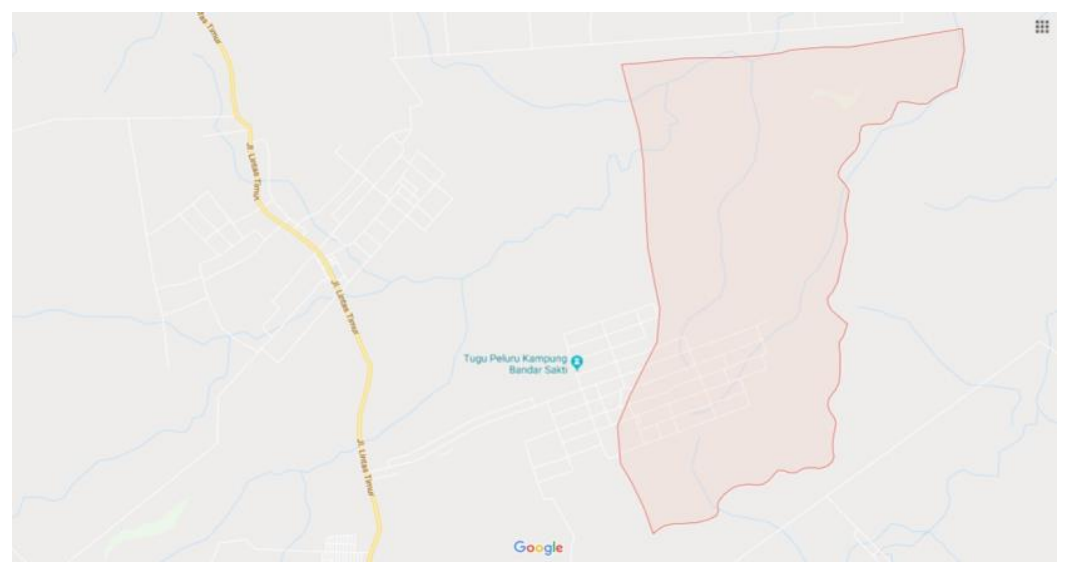

Gambar 1. Peta Kampung Tanjung Anom

Potensi alam dan Sumber Daya Manusia ini sangat didukung oleh dua perusahaan besar yang mengapit kampung ini, yaitu PT Great Giant Pineapple dan PT Gunung Madu Plantations. PT Great Giant Pineapple ini merupakan perusahaan swasta penghasil buah-buahan dengan tujuan ekspor maupun untuk mencukupi kebutuhan lokal. Selanjutnya PT Gunung Madu Plantations merupakan perusahaan gula yang bermitra tani dengan masyarakat kampung Tanjung Anom ini. Sehingga dapat dikatakan, potensi kampung ini sangat diuntungkan dengan adanya dua perusahaan ini, mulai dari tenaga kerja untuk proses produksi perusahaan tersebut, hingga membantu penyerapan hasil perkebunan para petani sebagai bahan baku produksi yang akan diolah di perusahaan tersebut.

Untuk menopang operasional perkebunan, di kampung ini terdapat sungai yang melintasi areal perkebunan. Sungai-sungai ini sangat vital perannya dalam keberhasilan perkebunan, hal ini dikarenakan air dari sungai digunakan untuk mengairi perkebunan-perkebunan di sekitar kampung tersebut. Lebih vital lagi, sungai ini juga berperan untuk memaksimalkan hasil dari 70 hektar perkebunan yang merupakan aset desa. Aset desa tersebut harapannya dapat menjadi Pendapatan Asli Desa (PAD) yang merupakan salah satu sumber Anggaran Pendapatan Belanja Desa (APBDesa) sehingga mampu memberikan dukungan keuangan bagi operasional administrasi desa dan peningkatan kesejahteraan masyarakat desa.

Permasalah yang timbul dalam pengelolaan perkebunan muncul ketika ketersediaan air sungai sering kali tidak mampu mendukung kebutuhan pengairan perkebunan, khususnya pada musim kemarau. Maka pada tahun 2013, Kepala Kampung berinisiatif membangun embung yang dapat menampung air singai dan air hujan sebagai sumber ketersediaan air pengairan. Proses pembuatan embung dimulai dari tahun 2013 hingga tahun 2017 dengan menggunakan dana yang berasal dari PAD. Dengan dibuatnya embung ini, ternyata mampu menyediakan pasokan air untuk pengairan perkebunan. Dapat dikatakan embung ini berhasil membantu petani dalam bercocok tanam, sehingga mampu mensejahterakan para patani di kampung ini.

Selain mampu memenuhi kebutuhan pengairan untuk perkebunan, ternyata embung ini juga dapat dimanfaatkan untuk kegiatan lain, seperti budidaya ikan air tawar. Selain itu, warga juga sering memanfaatkan lokasi embung tersebut untuk sekedar melepas penat melalui aktivitas memancing. Melihat aktivitas warga yang seperti itu, Kepala Kampung berinisiatif mejadikan 
embung tersebut menjadi lokasi wisata yang mampu mendatangkan PAD dan mampu mensejahterakan masyarakat.

Sebagai inisiatif usaha yang diharapkan mampu mendatangkan PAD dan mensejahterakan masyarakat, maka embung ini perlu dikelola secara profesional. Salah satu kesempatan profesional dalam mengelola embung desa ini adalah dengan membentuk Badan Usaha Milik Desa. Menurut Peraturan Menteri Desa, Pembangunan Daerah Tertinggal, dan Transmigrasi Republik Indonesia Nomor 4 Tahun 2015 Tentang Pendirian, Pengurusan Dan Pengelolaan, dan Pembubaran Badan Usaha Milik Desa (BUMDesa), BUMDesa merupakan badan usaha yang seluruh atau sebagian besar modalnya dimiliki oleh Desa melalui penyertaan secara langsung yang berasal dari kekayaan Desa yang dipisahkan guna mengelola aset, jasa pelayanan, dan usaha lainnya untuk sebesarbesarnya kesejahteraan masyarakat Desa. Namun untuk Tanjung anom, nama desa disebut dengan nama kampung. Maka terdapat sedikit penyesuaian, nama BUMDesa disesuaikan dengan nama Badan Usaha Milik Kampung (BUMK).

Untuk menindak lanjuti usulan pembentukan BUMK, pada tanggal 23 Januari 2017 Pemerintah desa bersama dengan Badan Permusyawaratan Desa (BPD) dan tokoh masyarakat yang mewakili masyaralat mengadakan musyawarah desa. Musyawarah desa tersebut akhirnya menghasilkan keputusan pendirian BUMK Tanjung Anom. Musyawarah desa ini merupakan syarat mutlak dalam pendirian BUMDesa. Selain itu musyawarah merupakan bentuk peningkatan komitmen partisipasi masyarakat dalam pembangunan kampung serta bentuk transparansi kegiatan pemerintahan kampung. Dalam musyawarah tersebut juga menunjuk pengelola BUMK. Pengelola BUMK yang ditunjuk adalah Ahmad Suryo Wibowo, seorang warga dari kalangan muda yang diharapkan mampu membawa perubahan dengan pengelolaan BUMK yang profesional.

Sebagai bentuk keseriusan Pemerintah desa, memului pemanfaatana Dana Desa, embung tanjung anom selajutnya dipercantik hingga kondisinya siap untuk dijadikan lokasi wisata. Tak ketinggalan, beberapa fasilitas permainan air pun disediakan di embung tersebut, seperti sepeda air dan saung apung.
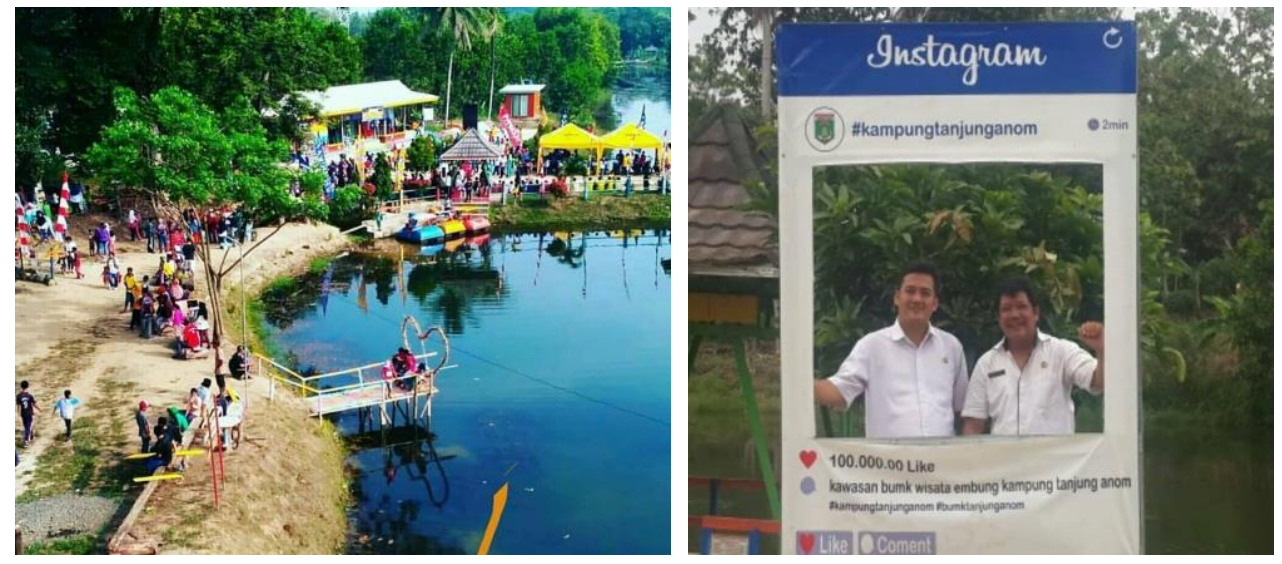

Gambar 1 Lokasi Wisata Embung Tanjung Anom

Embung ini secara remi dibuka untuk umum mulai bulan Februari 2018. Di awal beroperasinya embung ini, jumlah kunjungan sangat memuaskan. Alhasil pada bulan pertama mampu mendapatkan keuntungan hingga tiga juta rupiah. Pendapatan ini didapatkan dari sewa sepeda air dan kontribusi parkir saja, karena embung ini tidak memberlakukan tiket masuk. Dalam beberapa kesempatan, Bupati Lampung Tengah juga pernah melkukan kunjungan di embung Tanjung Anom ini. Bupati pun merasa gembira dengan adanya embung wisata di kampung Tanjung Anom ini. Hingga akhirnya Bupati Lamung Tengah ingin menjadikan Tanjung Anom ini sebagai destinasi wisata unggulan di Kabupaten Lampung Tengah.

Namun jauh panggang dari api, kejayaan ini tidak bertahan lama, sampai pada bulan ketiga, jumlah kunjungan langsung merosot drastis. Sampai dengan akhir tahun 2018, pendapatan pun sudah tak mampu menutupi biaya operasional seperti tenaga kerja dan perawatan fasilitas permainan. Kondisi ini diperparah dengan kondisi embung yang kian tak terawatt. Beberapa fasilitas sudah mulai rusak sehingga pengunjung pun enggan untuk berlama-lama di embung 
tersebut. Dengan demikian harapan masyarakat akan keberhasilan BUMK dalam mendatangkan PAD dan kesejahterakaan masyarakat mulai sirna.

\subsection{Perumusan Masalah}

Pengembangan potensi desa yang dikelola oleh BUMDesa di beberapa desa di Indonesia sudah mulai menunjukkan keberhasilanya. Tak khayal beberapa BUMDesa mampu mencetak penghasilan hingga milyaran rupiah dan mempekerjaan warga masyarakat yang masih menganggur. Namun hal ini cukup kontras jika kita melihat situasi yang berkembang dalam pengelolaan BUMK Tanjung Anom. Kondisi BUMK Tanjung Anom semakin lama kurang menjanjikan sebagai destinasi wisata, padahal kemajuan embung ini sangat dinanti oleh Pemerintah Kabupaten dan masyarakat. Untuk itu penulis merasa perlu diteliti permasalahan yang terjadi dalam pengelolaan BUMK Tanjung Anom selama ini. Selanjutnya, penulis mencoba merumuskan solusi untuk memperbaiki kondisi ini.

\section{METODE}

Metode pelaksanaan kegiatan pengabdian kepada masyarakat ini dilakukan dengan dua tahapan pelaksanaan, yaitu:

1. Focus Group Discussion (FGD),

Focus Group Discussion dilaksanakan untuk mendapatkan informasi tentang berbagai permasalahan yang terjadi dalam pengelolaan BUMK. Selain itu, FGD ini dilaksanakan untuk mendapatkan rencana penyelesaian dan langkah nyata dalam pengembangan BUMK ke depannya.

2. Pendampingan,

Pendampingan yang dilakukan dalam kegiatan pengabdian ini menggunakan metode pendampingan langsung maupun tidak langsung. Pendampingan langsung dilakukan dengan mendampingi secara langsung para pengelola BUMK secara langsung di lapangan. Pendampingan tidak langsung dilakukan dengan metode monitoring melalui alat komunikasi online.

\section{HASIL DAN PEMBAHASAN}

Hasil pengabdian kepada masyarakat ini mendapatkan beberapa hasil yang diharapkan mempunyai efek positif dalam pengembangan BUMK Tanjung Anom. Hal ini dibuktikan dari hasil yang didapatkan melalui tahapan metode yang telah direncanakan. Secara singkat hasil dari kegiatan pengabdian kepada masyarakata ini dapat digambarkan sebagai berikut.

\subsection{Focus Group Discussion (FGD)}

Focus Group Discussion dilaksanakan pada tanggal 30 Desember 2018 di rumah salah satu pengelola BUMK. Kegiatan FGD ini dihadiri oleh empat pengelola BUMK yang terdiri dari manager, bagian operasional lapangan, promosi, dan keuangan. Dalam kegiatan ini dilakukan diskusi untuk mendapatkan informasi tentang berbagai permasalahan yang terjadi dalam pengelolaan BUMK dan untuk mendapatkan rencana penyelesaian dan langkah nyata dalam pengembangan BUMK.

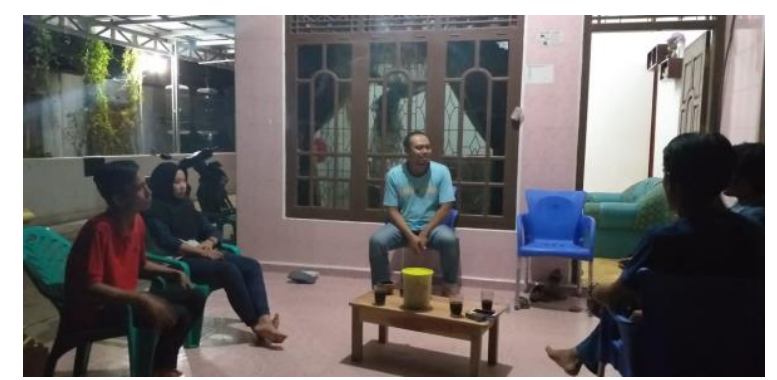

Gambar 2 Focus Group Discussion dengan pengelola BUMK 
Dari diskusi yang dilaksanakan mendapatkan berbagai informasi yang cukup baik untuk mengungkap permasalahan yang ada. Namun sebelumnya diskusi dibuka dengan pemaparan beberapa potensi dan peluang yang ada dalam BUMK Tanjung Anom. Potensi yang ada dimiliki oleh desa dalam mendukung pengelolaan BUMK dimulai dari luas lahan yang sangat memadai untuk dijadikan lahan wisata. Lahan ini juga sangat strategis karena lokasi desa dan embung Tanjung Anom sangat dekat dengan pintu keluar jalan Toll Terbanggi Besar Lampung Tengah, sehingga dapat menarik pengunjung dari kota-kota di Lampung seperti Bandar Lampung, Bandar Jaya, dan Metro. Selain itu, kedepannya akan dibangun jalan yang menghubungkan Terbanggi Besar ke Jalan Laintas Timur. Akses menuju lokasi juga telah didukung oleh kualitas jalan yang sudah bagus. Lokasi embung juga didukung oleh alat transportasi umum, sehingga sangat memudahkan pengunjung menuju lokasi jika tanpa menggunakan kendaraan pribadi.

Dari sisi permodalan untuk meningkatkan kuantitas dan kualitas fasilitas ternyata tidak terdapat masalah yang signifikan. Hal ini malah menjadi peluang bagi desa, dikarenakan seluruh infrastruktur fisik dan fasilitasnya telah didanai oleh Pemerintah Desa dengan menggunakan Dana Desa yang memprioritaskan pengunaannya untuk pengelolaan BUMDesa. Peluang yang lain adalah belum adanya lokasi wisata air di sekitar Kabupaten Lampung Tengah, sehingga peluang ini diharapkan mempu menyedot pengunjung lokal dari Lampung Tengah itu sendiri. Peluang yang bagus lagi adalah lokasi embung ini berada di kawasan industri pertanian, dengan karyawan yang memiliki pendapatan standar upah yang sesuai dengan Upah Minal Regional (UMR). Sehingga dengan pendapatan sesuai UMR ini mampu mendongkrak daya beli masyarakat.

Selain dari sisi potensi yang diharapkan mampu membantu perkembangan bisnis BUMK, terdapat pula permasalahan yang terdapat dalam pengelolaan BUMK Tanjung Anom ini. Permasahan yang paling mendasar terdapat pada Sumber Daya Manusia (SDM) pengelola BUMK. BUMK Tanjung Anom ini di kelola oleh kalangan muda yang energik, namun mereka belum punya pengalaman dan komitmen dalam menjalankan usaha. Mereka belum mempunyai keterampilan kewirausahaan yang baik. Selain itu mereka ini menjalankan usaha BUMK hanya sebatas kegiatan sambilan saja. Misalkan saja manager BUMK, Ahmad Suryo Wibowo, dia adalah seorang karyawan harian di salah satu perusahaan di sekitar desa tersebut. Dia memperoleh pendapatan sesuai dengan UMR yang ada, belum lagi jika dia mendapatkan pekerjaan lembur. Sehingga dia lebih memprioritaskan untuk bekerja di perusahaan dari pada mengelola BUMK secara penuh. Hal ini juga terjadi di pengelola yang lain. Praktiknya, pengelolaan ini terkesan menjadi kegiatan remaja untuk mengisi liburan akhir pekan saja. Sehingga dapat dikatakan SDM pengelola BUMK ini belum memadai secara kuantitas maupun kualitas. Maka yang perlu dirubah dari sisi SDM ini adalah cara pandang pengelolaan BUMK ini adalah pengelolaan sebuah usaha yang mendatangkan keuntungan, bukan sebuah kegiatan kumpul-kumpul remaja untuk mengisi liburan akhir pekan. Selanjutnya perlu ada perhatian khusus mengenai masalah SDM yang menjadi kunci pokok permasalahan kurang berkembangnya BUMK Tanjung Anom ini.

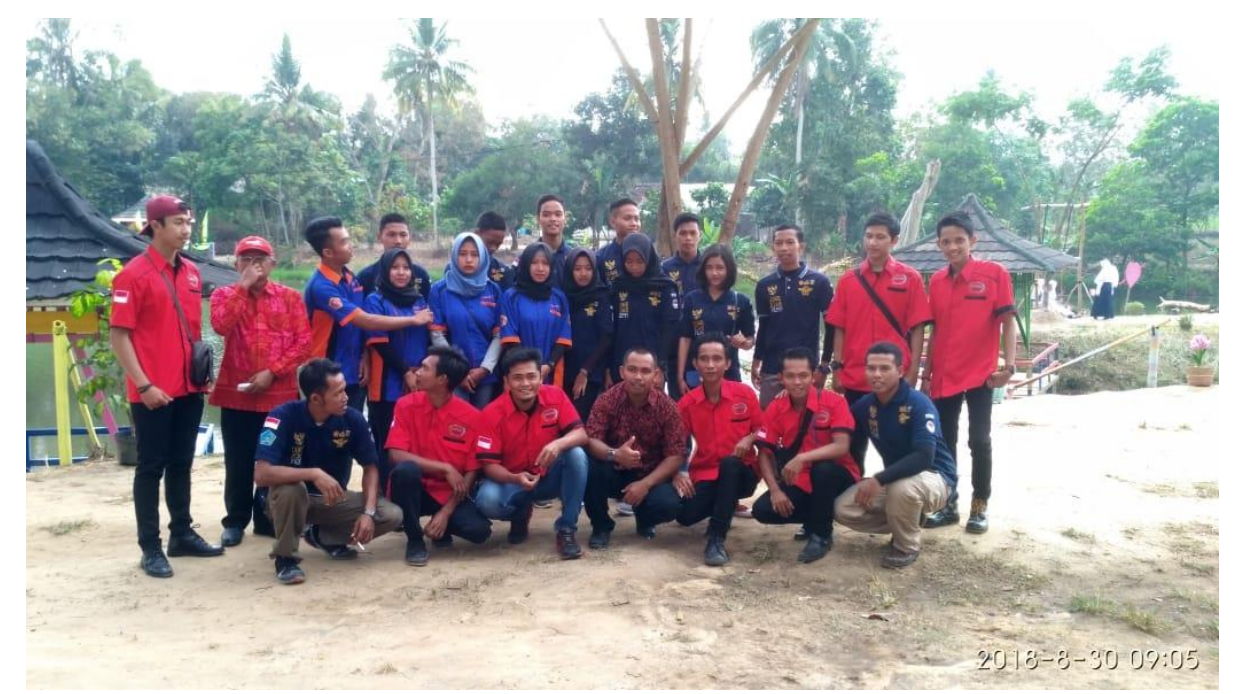

Gambar 3 Sumber Daya Manusia Pengelola BUMK 
Permasalahan yang lain adalah objek wisata embung Tanjung Anom ini belum dikenal oleh kalayak ramai baik di provinsi Lampung maupun Kabupaten Lampung Tengah itu sendiri. Sehingga perlu adanya sosialisasi atau pemasaran kepada masyarakat tentang beradaan objek wisata embung Tanjung Anom ini. Selain itu, perlu adanya inovasi berupa fasilitas wisata maupun kegiatan yang menarik pengunjung agar tertarik datang kembali ke embung Tanjung Anom ini.

Selanjutnya terdapat permasalahan administrasi keuangan. Saat pendapatan maupun pengeluaran sudah diadministrasikan atau dicatat dengan baik, namun mereka belum dapat membuat laporan keuangan secara baik. Sehingga mereka ini perlu mendapatkan pengetahuan mengenai pelaporan keuangan secara sederhana agar mudah diaplikasikan

\subsection{Pendampingan}

Permasalahan tidak dapat diatasi tanpa ada tindak lanjut penyelesaian masalah. Setelah kegiatan FGD mereka menyatakan akan berkomitmen mengembangkan BUMK Tanjung Anom. Untuk menjaga komitmen para pengelola BUMK, maka peneliti mencoba mendampingi kegiatan mereka dalam mengembangakan BUMK. Pendampingan yang dilakukan dalam kegiatan pengabdian ini menggunakan metode pendampingan langsung maupun tidak langsung. Pendampingan langsung dilakukan dengan mendampingi secara langsung para pengelola BUMK secara langsung di lapangan, namun metode ini tidak dapat dilakukan dalam waktu yang lama karena penngabdi berada di luar objek pengabdian masyarakat. Sehingga selanjutnya, pendampingan dilakukan secara tidak langsung dilakukan dengan metode monitoring dan advokasi melalui alat komunikasi online (yandra:2018). Pendampingan tidak langsung dalam ini menggunakan fasilitas Aplikasi Whatsapp. Dari aplikasi tersebut dibuat Whatsapp Group sehingga memudahkan bagi seluruh pengelola dan peneliti untuk bertukar pikiran hingga saling menyemangati satu sama lainnya.

Tindak lanjut dari FGD, pengelola yang berkomitmen kembali merapatkan barisan untuk memajukan BUMK. Ahmad Suryo Wibowo, selaku manajer BUMK rela untuk keluar dari pekerjaannya sebagai karyawan perusahaan. Komitmen ini yang sangat memotivasi rekan-rekan pengelola yang lain untuk berkomitmen pula mengembangkan BUMK. Agar tidak konflik dengan para pemuda yang dahulu pernah mengelola, para pemuda itu dipekerjaan hanya untuk kesempatan tertentu saja, misal sebagai juru parkir. Manajer BUMK juga rajin mengikuti pelatihan tentang pengelolaan usaha, selain meningkatkan kapasitas kewirausahaannya juga dapat menambah jaringan usaha.

Dalam menindak lanjuti permasalahan kurang terkenalnya objek wisata embung Tanjung Anom ini kemudian disiasati dengan menghidupkan kembali sosialisasi atau pemasaran embung Tanjung Anom melalui sosial media, selain itu pemasaran dilakukan pengelola dengan menjalin komunikasi dengan komunitas-komunitas yang berada di sekitar Lampung Tengah.
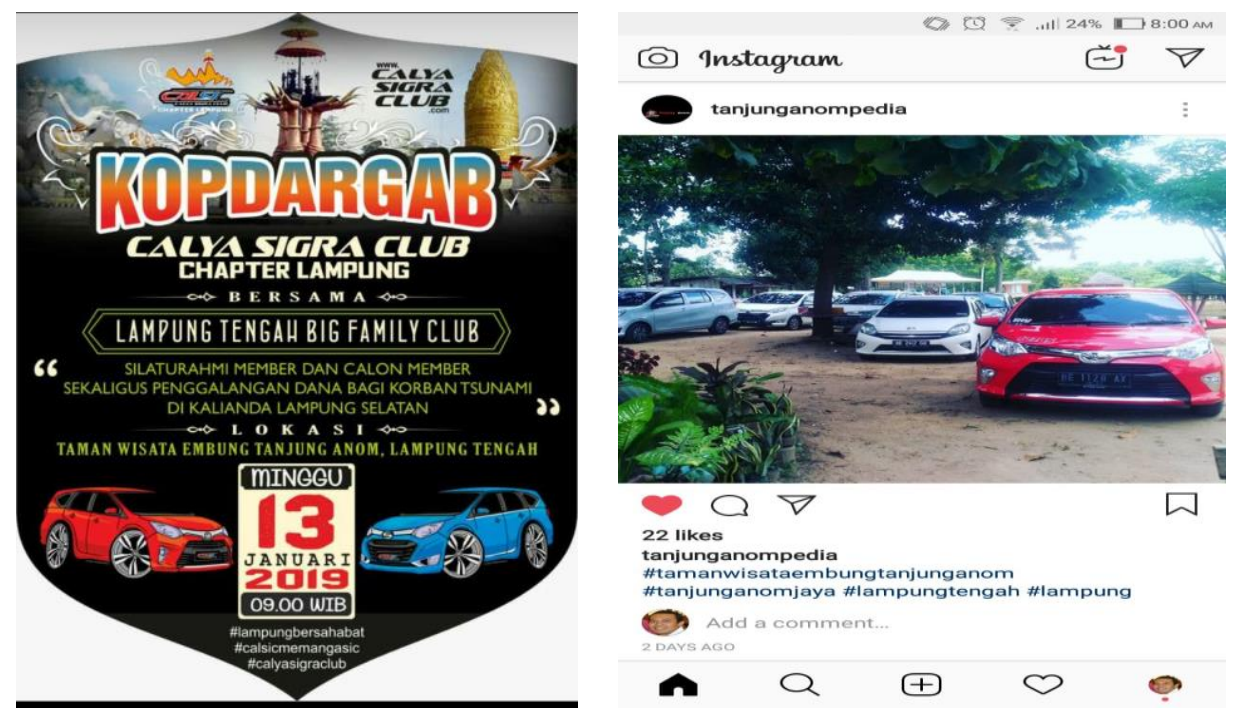

Gambar 4 Hasil sosialisasi BUMK melalui sosial media 
Hasil dari jalinan komukasi dengan komunitas dan sosialisasi melalui media sosial, embung Tanjung Anom menjadi lokasi acara pertemuan anggota komunitas mobil "calya sigra club". Kegiatan ini cukup semarak namun belum didukung dengan acara yang menarik para pengunjung. Selain itu, pengelola juga menambah failitas sepeda air dengan desain baru untuk lebih menyemarakkan embung.
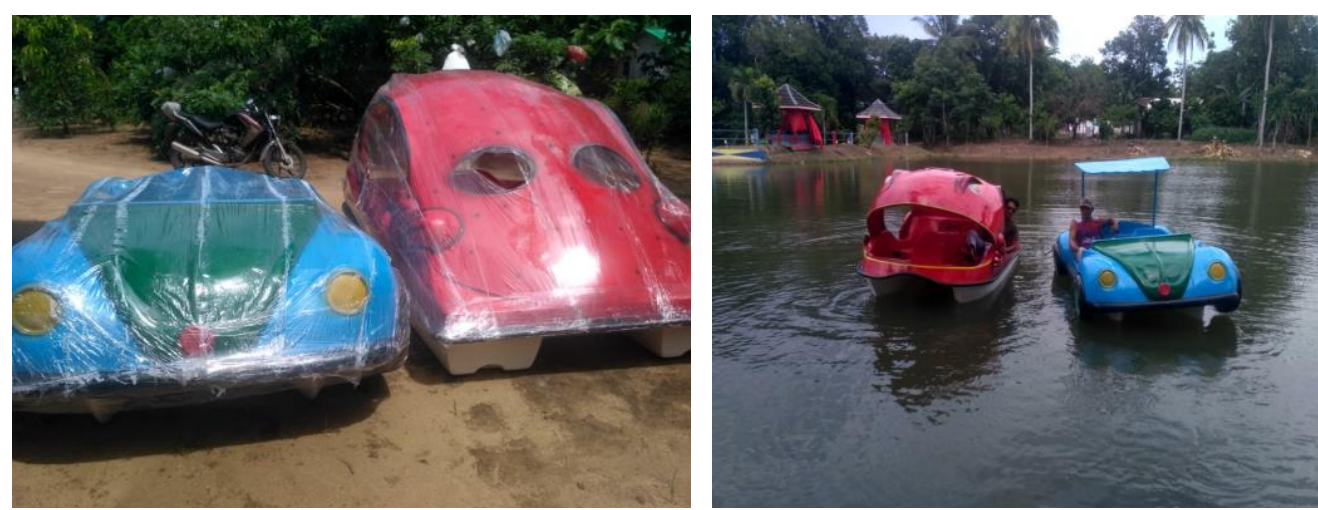

Gambar 5 Pengadaan sepeda air dengan desain baru

Terakhir, untuk pendampingan masalah administrasi keuangan BUMK belum dapat dilaksanakan. Solusi pemecahan ini sebenernya susah direncanakan dengan memberikan kegiatan pelatihan penggunaan aplikasi keuangan yang berbasis andoid. Namun rencana kegiatan tersebut belum dapat ditindak lanjuti karena peneliti perlu menggunana metode pendampingan langsung. Penyelesaian masalah ini akan menjadi kegiatan pengabdian kepada masyarakat kemudian.

\section{KESIMPULAN}

Setelah peneliti melaksanakan kegiatan pengabdian masyarakat ini, maka dapat disimpulkan bahwa permasalahan dan solusi keterpurukan BUMK Tanjung Anom adalah sebagai berikut:

1. Sumber Daya Manusia merupakan masalah mendasar yang menjadi kendala perkembangan BUMK Tanjung Anom ini. Permasalahan ini mulai terkikis setelah adanya komitmen penuh dari para pengelola BUMK.

2. Masalah kedua adalah pemasaran, objek wisarata embung Tanjung Anom ini belum terkenal di mata masyarakat sekitar. Hal ini di tindaklanjuti dengan menghidupkan kembali media sosial dan memjalin komunikasi dengan komunitas-komunitas yang ada di Lampung

3. Terakhir masalaah administrasi keuangan, hal ini belum kami selesaikan secara tuntas karena membutuhkan waktu yang relative banyak.

\section{SARAN}

Saran agar hasil pengabdian masyarakat ini mempunyai manfaat yang berkesinambungan, maka perlu adanya pendampingan secara berkelanjutan, baik pendampingan secara langsung maupun pendampingan secara tidak langsung. Pendampingan berkelanjutan tentunya bertujuan tetap menjaga komitmen SDM pengelola agar tetap fokus mengambangkan BUMK hingga pada tahap memberikan kontribusi pada PAD dan mensejahterakan masyarakat sekitar dengan dibukanya lapangan pekerjaan baru.

\section{UCAPAN TERIMA KASIH}

Penulis mengucapkan terima kasih kepada Politeknik Keuangan Negara STAN dan Pemerintah Kampung Tanjung Anom yang telah memberikan dukungan terhadap penelitian ini.

\section{DAFTAR PUSTAKA}


DINAMISIA - Jurnal Pengabdian Kepada Masyarakat Vol. 2, No. 2 Desember 2018, Hal. 347-354

[1] Peraturan Menteri Desa, Pembangunan Daerah Tertinggal, Dan Transmigrasi Republik Indonesia Nomor 4 Tahun 2015 Tentang Pendirian, Pengurusan Dan Pengelolaan, Dan Pembubaran Badan Usaha Milik Desa

[2] Kotler, Philip dan Kevin Lane Keller, 2009, Manajemen Pemasaran, Jakarta: Indeks.

[3] Rangkuti, Freddy, 2004, Analisis SWOT Teknik Membedah Kasus Bisnis, Jakarta: PT. Gramedia Pustaka utama

[4] UU No 6 Tahun 2014 tentang Desa

[5] Yandra, A. (2018). PELATIHAN PENGGUNAAN APLIKASI PENDETEKSI PALGIAT UNTUK DOSEN UNIVERSITAS LANCANG KUNING. Dinamisia: Jurnal Pengabdian Kepada Masyarakat, 2(2), 103-106. 